\title{
The decision-making process towards implementing energy efficiency in a university-built park in southern Brazil
}

\begin{abstract}
Sustainability has been increasingly incorporated as an essential life perspective into educational institutions as well as local communities. Universities play an important role into the society by debating theoretical contributions and implementing concrete actions. The present research was developed to evaluate a university's energy efficiency by using the Polytechnic University of Catalonia, Spain as a reference for University of Passo Fundo, Brazil. The reference values and index ratings obtained for energy performance, in the Universities' building stock, were evaluated based on positive and negative features. The study identifies and assesses the evolution of incident factors towards energy consumption and its impacts on the hidropower generation, the main energy resource in Brazilian. Hence, the university can promote a reflection about its practices to develop feasible tools that contribute to sustainable measures. As a result, guidelines and strategies were proposed, not only on targeted evaluated buildings but also on the entire building stock. The research indicates the importance to follow well-defined guidelines in the decision-making process by institutions of higher education, in order to consider integrated sustainable practices. The methodology and findings contribute to improve and promote Education for Sustainability, which should encourage other similar universities to put sustainable projects into practice and encourage the whole society to face the inevitable change of paradigms for achieving the Sustainable Development Goals (SDGs).
\end{abstract}

Keywords: energy efficiency, university buildings, university policies, decision-making process
Volume 5 Issue 6 - 202I

\author{
Marcos Antonio Leite Frandoloso,' Eduardo \\ Grala da Cunha, ${ }^{2}$ Albert Cuchí i Burgos ${ }^{3}$ \\ 'PhD, Universidade de Passo Fundo, College of Engineering and \\ Architecture, Civil and Environmental Programme, Brazil \\ ${ }^{2} \mathrm{PhD}$, Universidade Federal de Pelotas, Laboratory of Comfort \\ and Energy, College of Architecture, Brazil \\ ${ }^{3} \mathrm{PhD}$, Universitat Politècnica de Catalunya, ETSAB-ETSAV, Brazil
}

Correspondence: Prof. Marcos Antonio Leite Frandoloso, Ph.D., Universidade de Passo Fundo, College of Engineering and Architecture, Campus I, BR 285, km 292, São José, Passo Fundo/ RS, 99052-900, Brazil, Tel +55 54 99994-7887 +55 543601 2176, Email frandoloso@upf.br

Received: October 26, 2021 | Published: November 22, 2021
Abbreviations: SDG, sustainable development goals; HEI, higher education institutions; DESD, decade for education and sustainable development; UNESCO, united nations educational, scientific and cultural organization; BEN, national energy balance; EMS, environmental management system; ISO, international organization for standardization; UPC, polytechnic university of catalonia; UPF, university of passo fundo; PECR, resource consumption efficiency plans; POE, energy use projects; FEAR, college of engineering and architecture; NBR, Brazilian normative of reference; ABNT, Brazilian association of technical normatives; RTQ-C, technical energy efficiency level quality regulations for commercial, service and public buildings; ZB, bioclimatic zone; PROCEL, national electric energy conservation program; PMV, predicted mean vote; ASHRAE, American society for association of heating, refrigerating, and air conditioning engineers; RAC, compliance assessment requirements; VRF, variable refrigerant flow; PDI, institutional development plan; PAI, institutional environmental police; RSU, social responsibility university police; COP, coefficient of performance; UI, university of indonesia

\section{Introduction}

In recent years, energy efficiency concerns have become significantly important, as an environmental as well as an economic concern. As a result, national and/or international regulated initiatives, either mandatory or optional, have triggered a sense of environmental responsibility at universities worldwide including Brazilian universities. Higher education institutions (HEIs) play an important role in society's transformation towards integrating essential sustainability. One of the challenges presented by the
Talloires Declaration ${ }^{1}$ is that universities should «become an example of environmental responsibility by establishing conservation of resources, recycling and waste reduction programs», lately UNESCO's recognizes this role with the Decade for Education and Sustainable Development - DESD. ${ }^{2}$

According to Leal Filho, ${ }^{3}$ DESD was responsible for coordinating global efforts in order to address, through education; the social, environmental, economic and cultural goals of the twentieth century. It focused on three aspects: climate change, biodiversity, and disaster risk reduction. By supporting DESD ${ }^{4}$ however, HEIs are open to effectively incorporate new transformation practices into teaching, learning and management processes. As a result, the university is responsible, and must be committed, to include sustainability goals into their education, research, and exchange with society programs. In addition, such goals can be incorporated into the institution's own internal policies.

Unfortunately, DESD previous efforts either failed, or only partially met their goals. Leal Filho et al. ${ }^{5}$ states, based on a study involving several sources and stakeholders, that some HEIs are increasingly taking leadership on sustainable development more seriously and reflecting on them. In turn, sustainability leadership entails the processes, which leaders, policymakers, and academics undertake to implement sustainable development policies and other initiatives within their organizations. It includes a reflection of each HEIs decision-making process.

The expansion of university institutions in Brazil has increased in the past 30 years, due to the economic transformation of the information and knowledge's tertiary sector. Consequently, besides 
expanding the number of students; new courses and institutions have been created to respond to this growing demand. ${ }^{6}$ However, the absence of management strategies to execute contemporary urban structures, resulted in several issues related to the urbanization of rural areas to build new campuses. It has also impacted the city and suburban accessibility and mobility (access, traffic, means of transport), besides the impact on the natural environment (e.g. water flows, green areas, microclimate, air pollution).

Construction has a strong impact on natural resources as it consumes $14 \%$ to $50 \%$ of raw materials extracted from nature, $16 \%$ of water resources, and $40 \%$ of power sources, ${ }^{7,8}$ John et al. ${ }^{9}$ suggest, however, that buildings consume $75 \%$ of natural resources. The majority of these natural resources are non-renewable. They are also responsible for about $51 \%$ of electrical energy consumption ${ }^{10}, 75 \%$ of wood usage from the Amazon, ${ }^{11}$ and finally $60 \%$ of solid waste production. ${ }^{12}$ Brazil follows international standards, however, there's reduced information on the subject, especially due to lack of data concerning a building's life cycle at a national level.

In regard to the building construction section, housing represented $29.44 \%$, industry $34.73 \%$, business $19.12 \%$ and 16.715 to other constructions in 2019. In addition, the National Energy Balance $\mathrm{BEN}^{10}$ which includes all sectors, points to housing as representing $10.46 \%$ of the total primary energy consumption in the country, followed by the public and services $5.22 \%$. The electric sector and systems losses correspond $10.87 \%$; agriculture represent $4.36 \%$. The main consumption is associated to industrial production $33.89 \%$ as well as mobility and transport $35.26 \%$.

It's remarkable that Brazil has an electrical matrix of predominantly renewable origin, with highlighted by the water source that responds by $64.9 \%$ of domestic supply; renewable sources represent $83.0 \%$ of the domestic electricity supply. ${ }^{10}$

According to Tomashow, ${ }^{13}$ energy is fundamental to the organization as part of the efforts towards sustainability on university campuses. For the author, the issues related to energy use and activity management become part of «the nine elements of a sustainable campus», along with food, material flows, governance, investments, welfare, curricula, interpretation and aesthetics. They are considered more than a building supply, by serving as the direct connection between the campus and the biosphere. Also, to Tomashow, ${ }^{13}$ these elements inform the community about the organization's decisions. Based on their integrated implementation, there's great potential to promote leadership and consequently effective results. It encourages campus work on transformation, as well as its agents and the community to which the university has the role of supporting the sustainable ethos.

It is remarkable that, nowadays, energy policies have a transitional concept that combines the reality and the future,,${ }^{14}$ it contributes to a new design of a sustainable and innovation-conducive university campus, for instance by biophilia, ${ }^{15,16,17}$ which claims that the innate human need to connect with nature requires a radical modern society reform. In turn, universities have an important role to fulfill in order to meet such needs.

By a global perspective of the 2030 Agenda to achieve the Sustainable Development focusing in the Goal 7 - affordable and clean energy, the Sustainable Development Outlook $2020^{18}$ considerer a projected distance from the targets by 2030 at current trends, even with the post-COVID-19 effects; the reports shows a 5-10\% distance of promoting the access to electricity (7.1 strategy) and more than $10 \%$ to share of renewable energy (7.2) and energy intensity (7.3).
These gaps reinforce that, going forward, a greater partnership is still necessary among stakeholders, institutions, and nations for achieving the SDGs and in the new scenery of public health crisis.

The campus serves as a favourable environment for a new way of thinking about higher education. ${ }^{6}$ Therefore, it is imperative to establish universities as a centre that can contribute to incorporate all community and academic agents to work towards sustainability measurements. For instance, energy consumption can be reduced more efficiently and effectively when supported by changes in human scale. According to Tomashow, ${ }^{13}$ energy consumption behaviours are more likely to change when there is an adequate infrastructure that affects and influences its user's behaviour such as students/ future professionals, teachers, administrative staff, managers, and the community.

In regard to academic and administrative issues, several authors have pointed to energy consumption and its impacts on university's performance. Alshuwaikhat and Abubakar ${ }^{19}$ propose an integrated and systematic approach to achieve campus sustainability. The authors propose implementing either an Environmental Management System (EMS) according to ISO 14000 or an alternative method/ practice, ${ }^{20,21,22}$ towards public participation, social responsibility as well as sustainability teaching and research. According to Alshuwaikhat and Abubakar, ${ }^{19}$ there is a challenge to re-think and reconstruct environmental policies and practices in order to contribute to sustainable development at local, national and international levels.

Similarly, Faghihi et al. ${ }^{23}$ claim the focus on energy consumption reduction is a critical barrier to improve campus sustainability. They also demonstrate how efficiency, conservation efforts, and their interactions, impact improvement program performance under capital constraints. Based on a systematic and dynamic modeling approach, it captures and reflects casual feedback that drives program performance and requires performance measures on energy consumption as well as energy savings with a monetary correlation. Amber et al. ${ }^{24}$ also propose a forecasting model based on real data sets and buildings types (for academic and administration use). Both research projects show the importance of monitoring and analyzing the patterns for building energy and consumption.

Drahein et al. ${ }^{25}$ tested a procedure for assessing the adoption of sustainable practices in seven Brazilian HEIs. Before evaluating its national context, also analyzed by Frandoloso, ${ }^{26}$ a model was presented to identify practices adopted on service operations within five axes: governance/policies, people, food, energy/water and waste/ environment. This study focused on solid management waste, which reflected upon major practices and specific actions related to energy performance dimension. A methodological approach was developed by adjusting previous research projects and practical experiences by Universitat Politècnica de Catalunya - UPC. ${ }^{27,28}$ It also included new research guidelines adaptable to specific Brazilian characteristics at University of Passo Fundo - UPF. 6,26

The goal of this method is to develop an operative and management tool. It aims to support the decision-making processes to improve the efficiency of the existing built-up park. It allows an economic and environmental assessment of the repercussions each incident has in energy consumption as well as the habitability of higher education environments. However, it is also applicable to other functional typologies. The present article presents an excerpt of this methodology application in addition to results which emphasize energy aspects.

By analyzing the evolution of the factors involved in energy consumption, the goal is for the university to reflect upon its practices 
in all academic and administrative activities, in order to develop tools that contribute to Education for Sustainability and SDG 7, especially at the closure of infrastructural materials and energy cycles. ${ }^{28,29,30}$ It is imperative that the decision-making processes and normative instruments observe the guidelines presented here, because they enable evaluating investments and costs from an environmental management and design strategy implications. The present paper reports the $\mathrm{Ph} . \mathrm{D}$. thesis developed by Frandoloso ${ }^{26}$ making a summary of the whole work.

In addition, this study can reflect and contribute to, not only with a sustainability assessment by infrastructures and building stock of University of Passo Fundo, but also to similar HEIs or even similar buildings stock parks (e.g., public complex, schools, administrative campuses).

\section{Methodology of assessment}

\section{Energy audit methodology}

The starting point of this research displayed the experiences of Polytechnic University of Catalonia - UPC. In order to attend to the European Directives, it discusses and applies various planning activities and natural resource management as well as their impact towards the university campus and building stock. ${ }^{27,28,31}$ It also associates applicable strategies for higher education ${ }^{32}$ and evaluates concrete actions. Some of these actions took place in the Department of Technology in Architecture and involved the $\mathrm{PhD}$ program in Architecture Research, Energy and Environment at UPC.

This article presents the application of reference values and index ratings obtained from thermal and energy performance in the university buildings. Moreover, a brief example of sustainability on campus was also presented by Frandoloso ${ }^{33}$ who evaluated the positive and negative factors on this project, and lead to a new methodology that verifies its applicability in another university context, in this case, the University of Passo Fundo - UPF, located in southern Brazil.

Creating a new approach entailed adjusting and improving previous reference methods in order to contextualize Brazilian and UPF's profile characteristics. This methodology was utilized as a reference point for natural resource management tools and their economic repercussion towards university policies and concrete actions.

The study was developed with methodological references implemented at UPC, based on Energy Audits. ${ }^{34,35,36}$ It incorporated effective projects developed by the Resource Consumption Efficiency Plans - PECRs, especially from Energy Use Projects (POEs), implemented by UPC. ${ }^{31-37}$ Such procedures were adjusted and contextualized for UPF's evaluation ${ }^{26}$ as it is represented by Figure 1.

Based on the Energy Audit methodology, two groups of information were evaluated with a pragmatic approach: a static data group (without temporal variations such as architecture and construction data as well as location) and a dynamic data group (with temporal variations such as energy consumption, intensity of use and occupation, environmental variables and management). The dynamic data was obtained by modelling the occupied area, the number of users and activity types, generating schedules and usage profiles. They correspond to Phase 1 of the diagram - inventory and mapping data (Figure 1). In addition, three other phases were also structured: Evaluation, Diagnosis and Lines of Action as well as Intervention Proposals.

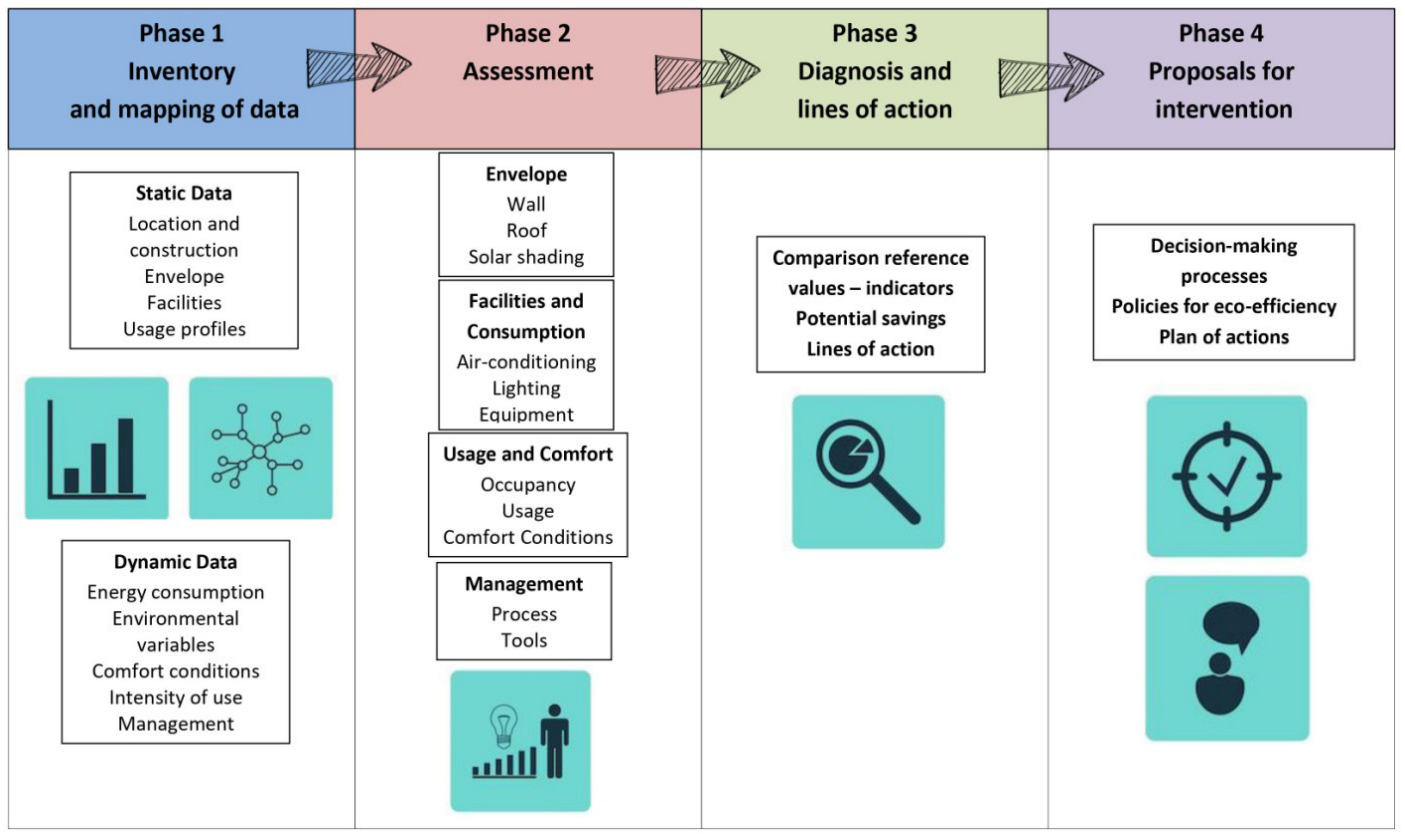

Figure I Energy assessment methodology.

The real conditions of the selected buildings were simultaneously obtained through indoor temperature and humidity measuring devices (Data-loggers Testo, models 175-H2 and 175-T1), analogical energy gauges and monitoring systems SmartGateM. ${ }^{38}$ The comparative energy and thermal performance analyses were generated by the software DesignBuilder, ${ }^{39}$ that also generated results about indoor thermal comfort conditions.

The research stages were then defined based on UPC's experience. It states 5 steps to be considered in this process. Figure 2 presents a flow chart of the developed research considering five aspects: 


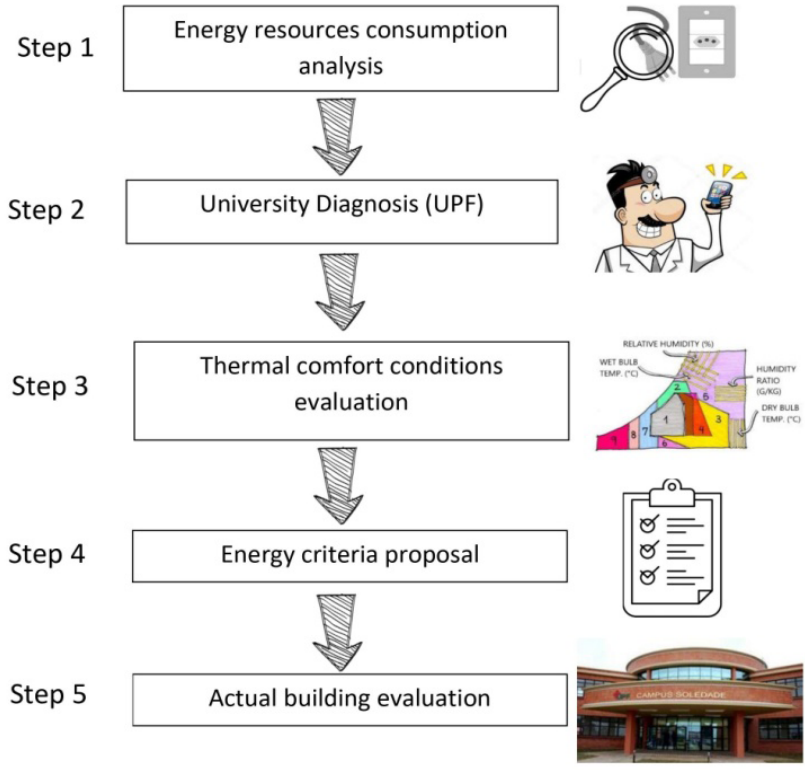

Figure 2 Research flow chart.

I. Step 1 - Factors analysis involving energy resources consumption in the university buildings (demand, management and equipment yield);

II. Step 2 - UPF's diagnosis of efficiency context, with emphasis on energy use;

III. Step 3 - Evaluation of comfort conditions in academic environments. Evaluation of corresponding performances of architectural variables and building systems;

IV. Step 4 - Proposition of decision-making criteria for energy efficiency;

V. Step 5 - Evaluation of actual building conditions. Comparison simulations from ideal theoretical models to promote envelope and systems improvement.

The incidental factor assessment evolution in energy consumption is intended to demonstrate how it is possible for UPF's administrative staff to develop strategic and integrated plans. It can assess investments, costs and the implications of environmental management and design, that corresponds to power and emissions strategies. As a result, the following questions have been brought up, based on such research proposition: "Can these strategies be effectively applied by economic and administrative budget cuts or by commonly adopted administrative practices? What is the real impact among the decisionmaking process, administrative policies and the positive outcomes of an eco-efficient building stock?"

The overall objective of the research focuses on proposing applicable criteria, methods and processes to implement energy efficiency at UPF. Besides, it seeks to improve thermal performance within learning and workspaces. The present research focuses specially on transforming such methodology into a feasible and operational tool. In other words, it aims to build up instruments and guidelines for decision support, in order to improve the performance of existing and new buildings; to allow an accurate assessment of the impact of incidental factors in energy consumption. The main challenge of such assessment, however, is to rationalize the decisionmaking process, in order to reduce management and usage costs and to develop alternatives to stocks and investments.
Although this type of work is increasingly being adopted in contexts of developed countries, in developing countries such as Brazil and Latin America, for example, the implementation of these practices continues to be restricted, both by economic and political issues but also by the lack of infrastructure planning processes. This fact places an importance on the role of research that drives a shift towards the UN SDGs.

\section{Research scope: UPF and the field of study}

UPF is a community university and a non-profitable institution with seven campuses; therefore, it has a regional influence on the North of the State of Rio Grande do Sul, in Southern Brazil. The main campus in the city of Passo Fundo has 341ha, located on the surroundings of the urban area Figure $3 \& 4$. This campus is responsible for almost $85 \%$ of the entire energy consumption of the university campuses, which justifies the importance to assess how its buildings and infrastructures deal with energy issues and indicate measures to improve their efficiency. ${ }^{40}$

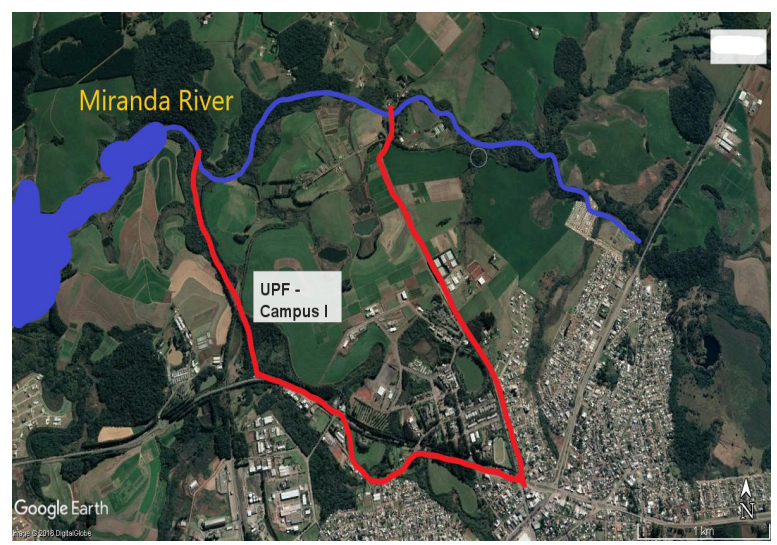

Figure 3 Passo Fundo urban area and UPF's Campus I..$^{26}$

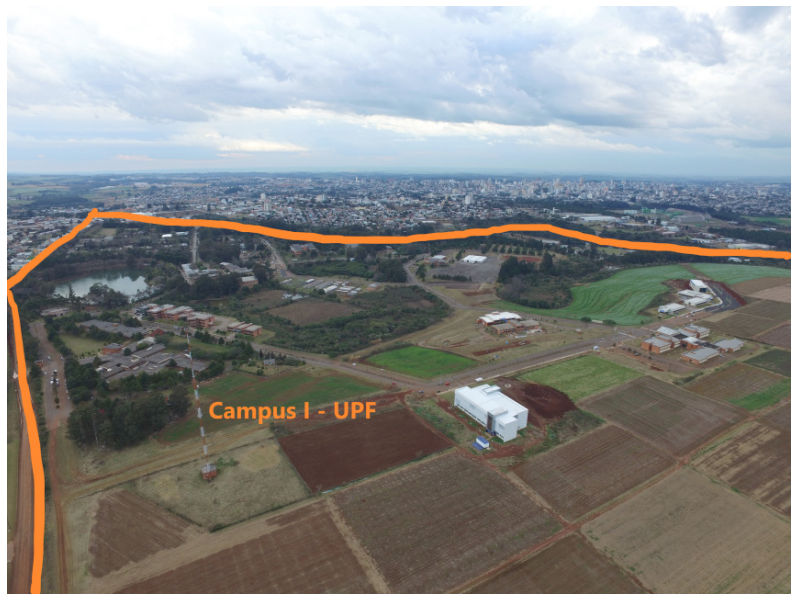

Figure 4 Campus I and urban neighbourhood. ${ }^{26}$

As part of the study's goals, two university buildings in different stages were selected. Both buildings were built within the last 45 years (created in 1973) and were chosen due to their construction typologies as well as their usage and occupancy factors: Figure 5a hosts administrative and teaching blocks from the College of Engineering and Architecture (CEA) - Building G1; Figure 5b presents a building with laboratories and classrooms. It hosts the CEA and the Centre for Research in Agriculture. In these paper two rooms from each building were selected, located in opposite directions, according to the thermal multi-zones showed by the Figure $6 \mathrm{a}$ and $6 \mathrm{~b}$. 


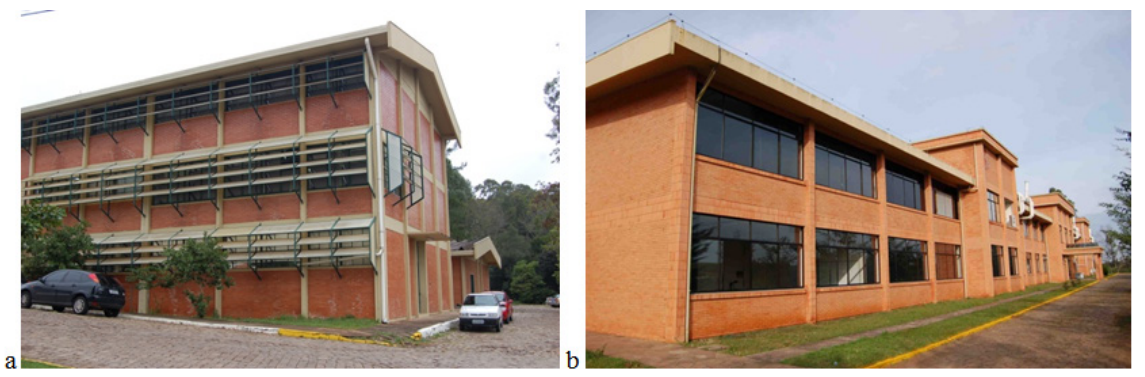

Figure 5 Building GI - Northeast Facade (a); Building LI - North Facade (b). ${ }^{26}$

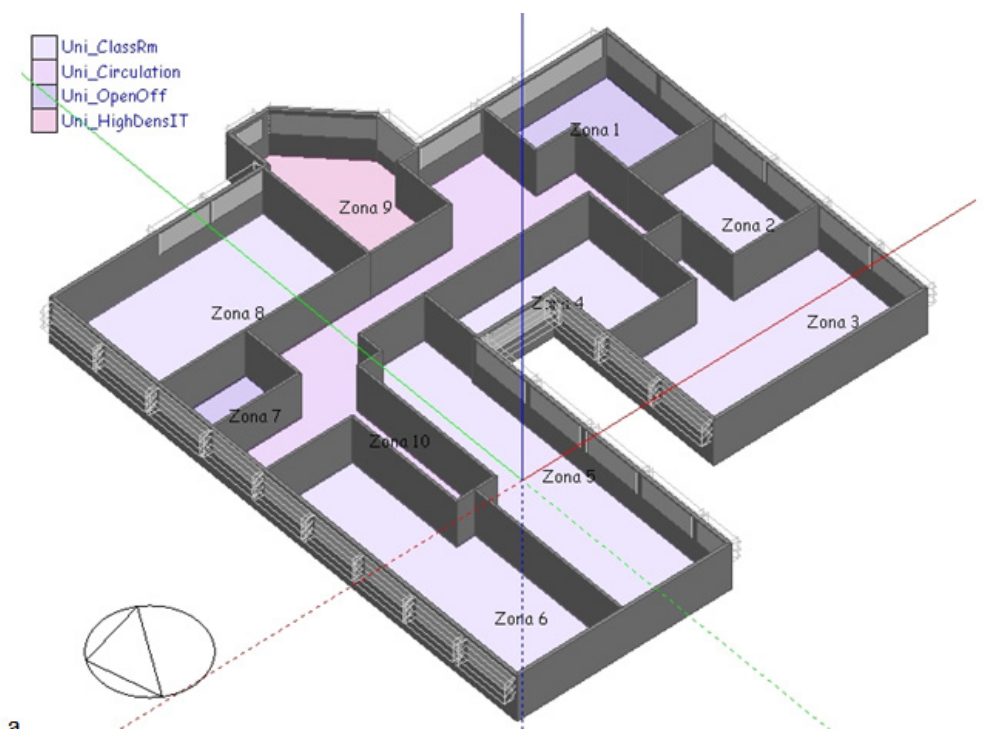

a

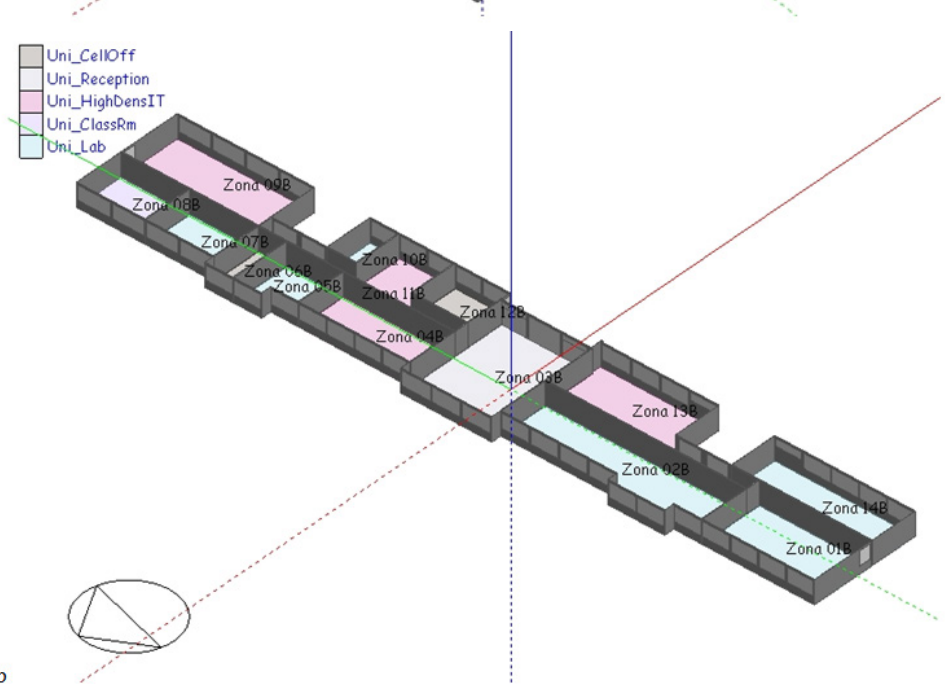

Figure 6 Building GI:Thermal multi-zone, upper floor (a); Building LI:Thermal multi-zone, upper floor (b). ${ }^{26}$

\section{Analysis of results}

\section{Static and dynamic data}

The different methodological application stages resulted initially in the characterization of the building envelopes with the heat transfer coefficient (U-value), corresponding to Phase 1. In addition, it also resulted in the static data evaluation according to NBR15220 $0^{41}$ and NBR $15575^{42}$ indicated by Bioclimatic Zone 2 (ZB2) where Passo Fundo is located. This information was calculated by the program DesignBuilder and adopted as a simulation tool.
The static data of the envelope of G1 Bld. is characterized by the current construction system from the 1980s, with single masonry walls and expanded polystyrene ceiling on the upper floor. L1 was built in the most recent typology (1990s) with double brick walls and concrete ceiling. Cross-results shows the classification of the envelope's energetic efficiency level. They observe Brazilian's Technical Energy Efficiency Level Quality Regulations for Commercial, Service and Public Buildings- in Portuguese RTQ-C, ${ }^{43,44}$ and were framed at level "B" for walls and level "C" or "D" for both building roofs, as shown in Table 1 below. 
Table I U-value according to RTQ-C for ZB2 and GI and LI classification ${ }^{6}$

\begin{tabular}{llll}
\hline \multicolumn{2}{l}{ Roof } & \\
\hline Quality level & Air-Conditioned & Non-conditioned & External walls \\
\hline A & $\mathrm{U} \leq 0.5 \mathrm{~W} / \mathrm{m}^{2} \mathrm{~K}$ & $\mathrm{U} \leq 1.0 \mathrm{~W} / \mathrm{m}^{2} \mathrm{~K}$ & $\mathrm{U} \leq \mathrm{I} .0 \mathrm{~W} / \mathrm{m}^{2} \mathrm{~K}$ \\
B & $\mathrm{U} \leq 1.0 \mathrm{~W} / \mathrm{m}^{2} \mathrm{~K}$ & $\mathrm{U} \leq 1.5 \mathrm{~W} / \mathrm{m}^{2} \mathrm{~K}$ & $\mathrm{U} \leq 2.0 \mathrm{~W} / \mathrm{m}^{2} \mathrm{~K}(\mathrm{GI}$ y LI) \\
C and D & $\mathrm{U} \leq 2.0 \mathrm{~W} / \mathrm{m}^{2} \mathrm{~K}(\mathrm{Gl}$ y LI $\left.)\right)$ & $\mathrm{U} \leq 3.7 \mathrm{~W} / \mathrm{m}^{2} \mathrm{~K}$ \\
\hline
\end{tabular}

In order to classify the static data, the use and occupancy of all environments were monitored as well as the energy consumption, ${ }^{6}$ as shown in Table 2:

The control of energy consumption is centralized on Campus I. However, a new system was set up in all energy consumption units (SmartGateM - Gestal) between 2009 and 2012, that allowed to control and monitor on-line energy consumption. The energy consumption monitoring automatically takes place when pre-established limits were exceeded. In addition, energy dependent installations can be disconnected or activated with a self-generating equipment. This equipment is used to control consumption fines and surcharges from $6 \mathrm{pm}$ to $9 \mathrm{pm}$.

Table 2 Static and dynamic data and theoretical energy demand ${ }^{6}$

\begin{tabular}{|c|c|c|c|c|c|c|c|c|}
\hline Bld. & $\begin{array}{l}\text { Surface } \\
\left(\mathrm{m}^{2}\right)\end{array}$ & Occup. & $\begin{array}{l}\text { Condit. Surface } \\
\left(\mathrm{m}^{2}\right)\end{array}$ & $\begin{array}{l}\text { Condit. Power } \\
(\%)\end{array}$ & $\begin{array}{l}\text { Equip. Power } \\
(\%)\end{array}$ & $\begin{array}{l}\text { Light. } \\
(\%)\end{array}$ & $\begin{array}{l}\text { Total Power } \\
\text { (W) }\end{array}$ & $\begin{array}{l}\text { Density (W/ } \\
\mathrm{m}^{2} \text { ) }\end{array}$ \\
\hline GI & 2696.56 & 863 & 624.11 & 25.56 & 62.1 & 12.34 & 304.668 & 113.06 \\
\hline LI & 3389.77 & 645 & 988.7 & 29.28 & 63.67 & 7.05 & 539.66 & $|59.2|$ \\
\hline
\end{tabular}

Based on the assessed period results (from 2009 to 2012), it was possible to trace the evolution of energy consumption (Figure 7). Greater energy demands were identified by the installed equipment (personal computers), as well as by an increasing number of students which represented approximately $118 \%$ from 2003 to 2014 and $28.10 \%$ from 2009 to 2012 . These indicators are reflected in annual total energy consumption, increasing in $96.00 \%$ in G1 for the building that holds the main classroom occupation, and $63.05 \%$ in L1 where laboratory use is predominant.

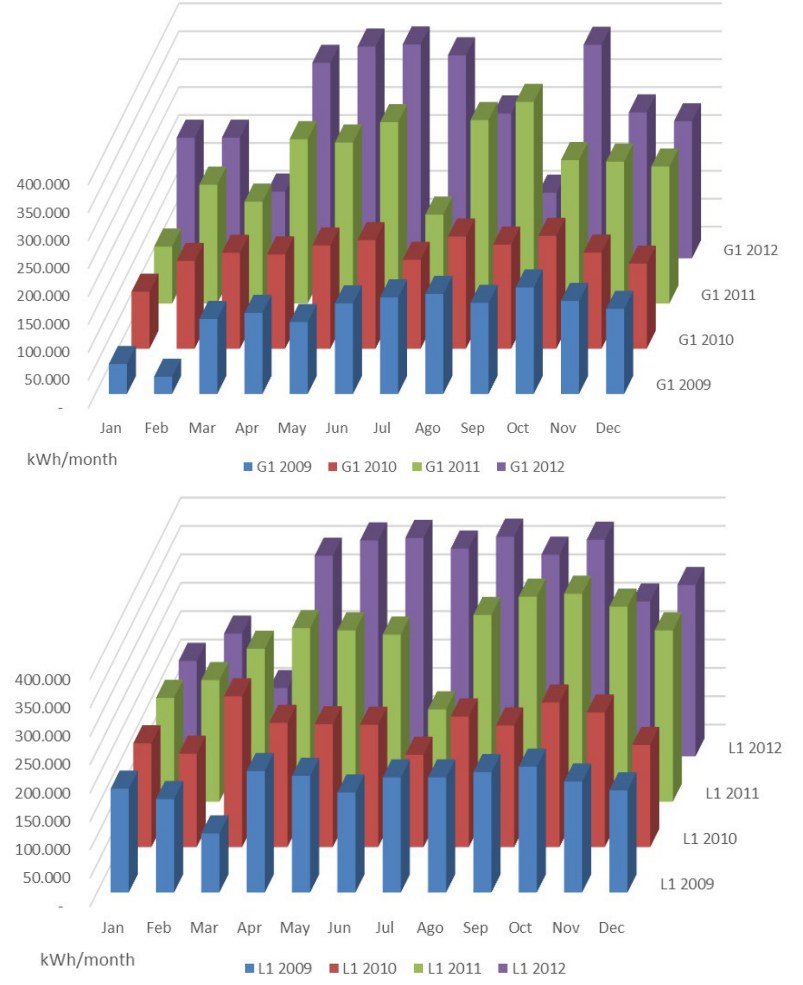

Figure 7 Comparable monthly energy consumption in buildings $\mathrm{GI}$ and L from 2009 to $2012{ }^{6}$

\section{Thermal comfort conditions}

In order to assess users' well-being, the Fanger's Predicted Mean Vote $-\mathrm{PMV}^{45,46}$ was adopted. PMV includes internal and external environment variable averages (radiant mean temperature, air temperature, air humidity and relative air speed) and global temperature to generate standard values. In addition, internal environment thermal tolerance is subject to ISO $7730^{47}$ pattern regulations. PMV or analytic sensation for thermal comfort values were obtained through thermal balance between man and environment.

DesignBuilder was used to identify indoor thermal comfort conditions. A total of 4 rooms from both buildings were evaluated and classified according to the ASHRAE Bedford thermal sensation scale. ${ }^{48}$ To make the climate characterization was adopted an epw file, as showed by the Figure 8; the figure also allows to stablish the correlations with the monthly energy consumption presented in the Figure 7, related to climate conditions and occupancy schedule.

Table 3 displays a comparison of all 4 thermal areas based on its environmental monitored variables by data-loggers equipment. These areas are the following: Zone 5 situated in the ground floor where the Office of Architecture and Urbanism Courses was located. Upper zone 1 - Office of Environmental Engineering. Ground floor 2/2A- Processed Meats Laboratory and ground floor 5A - Classroom Practices Laboratory.

Results from the software simulation present (Table 3) the annual PMV thermal zones index values. They state that spaces from building G1 present sensations close to -1 (comfortably cool) and even values from building L1 are classified in the Bedford scale ${ }^{48}$ with positive indexes (hot). A heat discomfort sensation was reported at the Meat Laboratory due to the heat generated from the cooking equipment.

Due to the fact the air-conditioning systems presents a reduced used area in operation of $23.14 \%$ at G1 and $20.17 \%$ at L1 (Table 2 ), it means a partial coverture of the equipment; a complementary methodology of adaptive comfort was adopted for naturally ventilated spaces, ${ }^{49,50,51,52}$ referenced by the ASHRAE Handbook - Fundamentals, ${ }^{53}$ and applied in Brazil by Negreiros. ${ }^{54}$ The dataloggers used to register the real indoor environmental variables of 
temperature and humidity, presented in the whole work developed ${ }^{26}$ confirms these results.

Considering the percentage of occupied hours, generated by usage reports (from 8:00am to $10: 30 \mathrm{pm}$ ), there is a predominantly comfort sensation of $73.46 \%$ of the hours in building G1. The heat conditions slightly exceeded cold ones, $15.10 \%$ and $11.44 \%$ respectively, as showed in Figure 9.

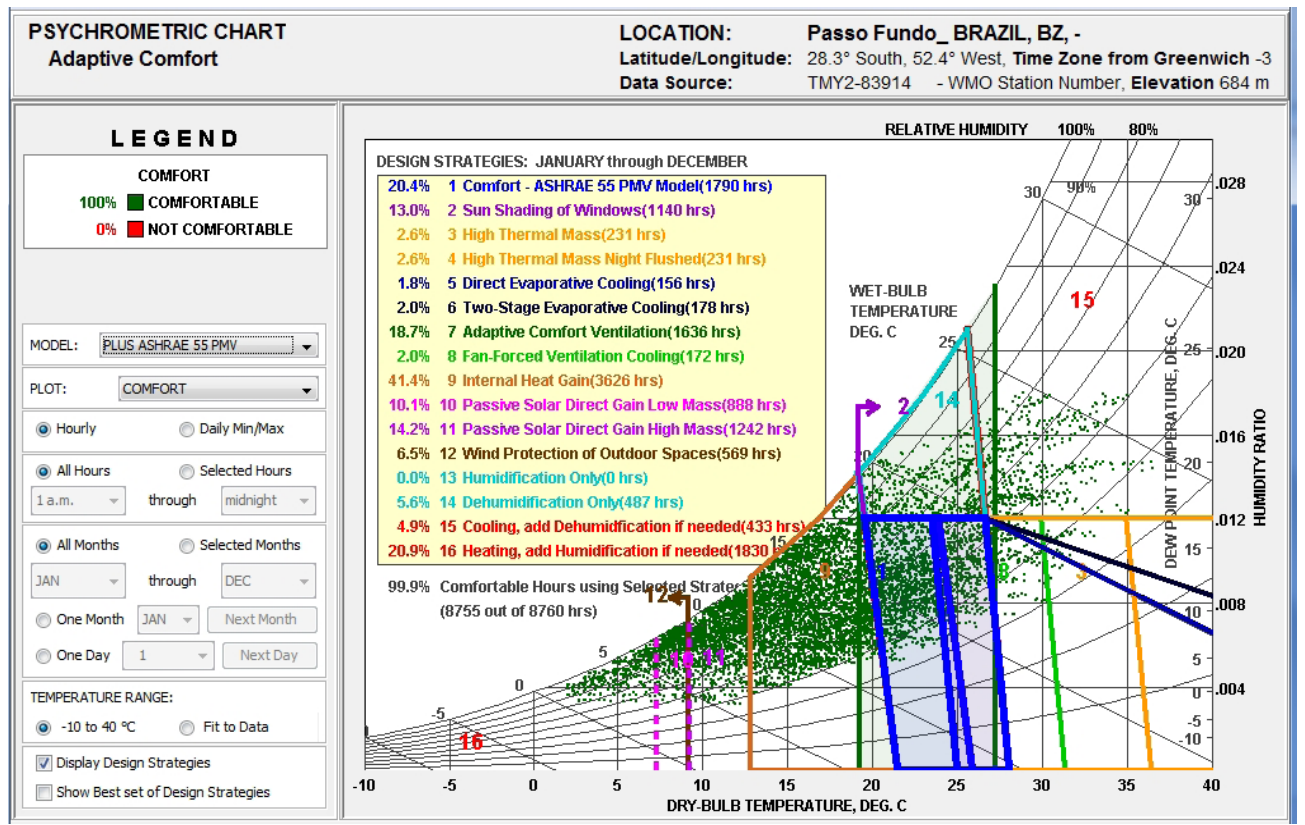

Figure 8 Psychrometric Chart - Adaptive Comfort by Climate Consultant. ${ }^{6}$

Table 3 Thermal comfort conditions in thermal areas based on software simulations ${ }^{6}$

\begin{tabular}{llllll}
\hline Bld. & Room/Solar orientation & Summer Discomfort (h) & Winter Discomfort (h) & All Clothing (h) & Annual PMV \\
\hline GI & Arch. and Urb. (NO) & 1958 & 1465 & 929.5 & -1.067 \\
& Environ. Eng. (SE) & 2074 & 2333 & 2592 & -0.847 \\
LI & Meat Laboratory (NNO) & 3395.25 & 3176 & 2968 & 0.567 \\
& Practices Lab. (SSE) & 2481.5 & 2374.25 & 2363.5 & 0.224 \\
\hline
\end{tabular}

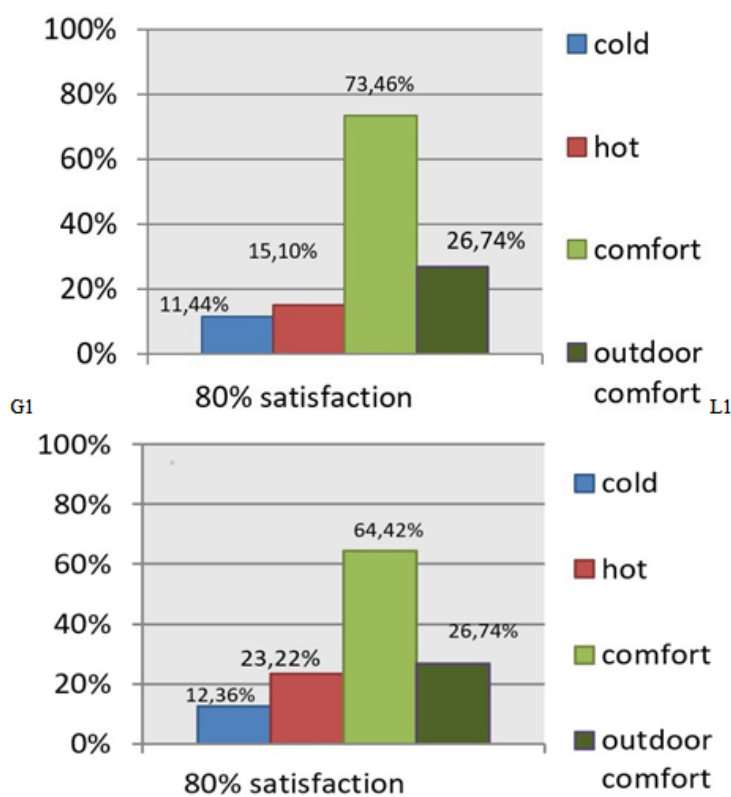

Figure 9 Adaptive thermal comfort conditions: GI and LI. ${ }^{6}$

\section{Modeling results}

To achieve the assessment goals, the energy modelling describes the process of creating or using a model that focus on energy as an economic resource, to capture characteristics of real systems and represents in a computer the behavior that the system would present in the same boundary conditions as in reality. ${ }^{55,56}$ Energy and performance models can have data incorporated which allows to make better decisions in the processes of buildings design and controls in a way to increase the performance and control an energy system. ${ }^{57}$

All previous phases and data analysis presented in Figure 1 , allowed the development of different simulation models by DesignBuilder. They were also compared with the actual results of energy consumption obtained from a monthly follow-up by the SmartGateM monitoring system.

In Phases 2 and 3, the comparison between the simulated reference model $\mathrm{R}$ and the actual measured data for each of the analysed buildings and scenarios were established for the theoretical models, according to Figure 10:

Theoretical Model T1: conditioning of all permanent activity spaces, in order to cover the demands of thermal comfort condition 
improvement, under the criteria defined by the Brazilian directives RTQ-C $\mathrm{C}^{43,44}$ and RAC - Conformity Assessment Requirements for Building Energy Efficiency ${ }^{58}$ for the certification in level "A";

I. Theoretical Model T2: in addition to environment conditioning, the impact of portable computers usage increase by students, as well as changes in the envelope were also evaluated, according to the criteria of RTQ-C and RAC;

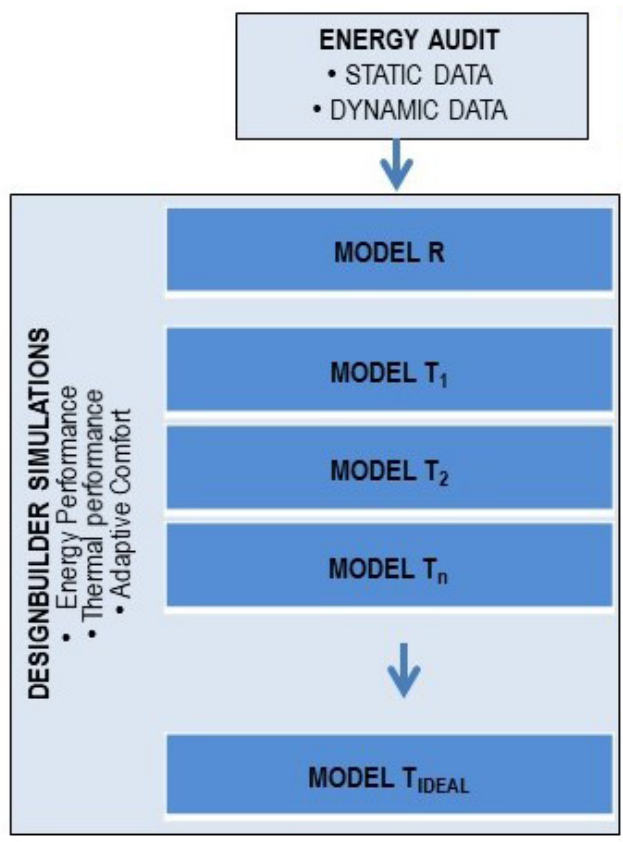

II. Theoretical Model Tn: developing alternative models and combining results, if necessary, in order to meet the assumptions of previous evaluations;

III. Theoretical Model Tideal: definition of the most appropriate model for the research requirements and conditions.

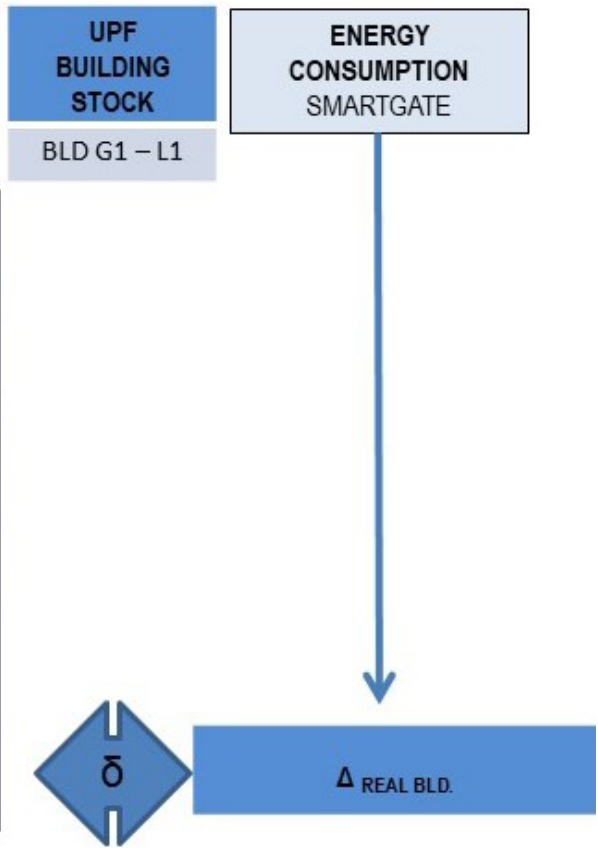

MODEL $T_{\text {FINAL }}$

G1

L1

Figure 10 Simulation models and real input. ${ }^{26}$

The models aimed at improving efficiency, either through different strategies in the envelope (thermal insulation and absorptance, sun protection, transparent closures/frames), or by better use and management of equipment and systems. These models also considered the profiles of users, schedules of occupancy, lighting devices, equipments etc.

In order to reach the definition of an ideal Tideal theoretical model, real results were compared. From the identification of the differentials $\delta$ between the ideal simulation situation and measurement, the real building's equivalence $\Delta$ RealBuilding was obtained, and consequently, the definition of the theoretical model Tfinal, also represented by Figure 8 .
The results of all simulations - Phase 3 - are represented by the correlation of each of the variables according to Table 4, by comparing the results with the reference model $\mathrm{R}$ using a percentage deviation. The representation Figure $(11 \& 12)$ is dimensionless in order to have different variables and units compatible such as:

- electricity (lighting, equipment and computers), heating and cooling related to model R (\%);

- conditioned areas of the building (\%)

- thermal comfort of occupied hours (\%);

- envelop formed by walls and roofs compared to the minimum U coefficient for level A according to RTQ-C.

Table 4 Variable corelations for each simulation model ${ }^{26}$

\begin{tabular}{|c|c|c|c|c|c|c|c|}
\hline Bld Model \#I \#2 & Energy & Heating & Cooling & Conditioned Areas & Thermal Comfort Hours & UWalls & U Roof \\
\hline GI_R & 0 & 0 & 0 & 0.23 & 0.73 & -0.33 & $-1.7 \mid$ \\
\hline GI_TI & 0.01 & 1.42 & 0.17 & 0.74 & 0.77 & 0.01 & 0.02 \\
\hline GI_T2 & 0.02 & 2.31 & -0.09 & 0.74 & 0.79 & 0.01 & 0.02 \\
\hline GI_T3 & 0.62 & -0.43 & 0.48 & 0.23 & 0.52 & -0.33 & $-1.7 \mid$ \\
\hline
\end{tabular}


Table Continued...

\begin{tabular}{|c|c|c|c|c|c|c|c|}
\hline Bld Model \#I \#2 & Energy & Heating & Cooling & Conditioned Areas & Thermal Comfort Hours & UWalls & U Roof \\
\hline GI_Ti & -0.22 & 2.06 & -0.33 & 0.74 & 0.79 & 0.01 & 0.02 \\
\hline LI_R & 0 & 0 & 0 & 0.29 & 0.64 & -0.13 & -1.72 \\
\hline LI_TI & 0.03 & 5.25 & $\mid .31$ & 0.85 & 0.87 & 0.12 & 0 \\
\hline LI_T2 & 0.06 & 2.7 & I & 0.85 & 0.84 & 0.12 & 0 \\
\hline LI_T3 & 0.02 & 2.97 & 0.66 & 0.85 & 0.88 & 0.12 & 0 \\
\hline LI_T4 & 0.12 & -0.02 & 0.01 & 0.85 & 0.63 & 0.12 & 0 \\
\hline LI_Ti & -0.14 & 2.81 & 0.51 & 0.85 & 0.88 & 0.12 & 0 \\
\hline
\end{tabular}

\#'Building GI: Model R - reference; Model TI: extension of the conditioned areas; Model T2: extension of the conditioned areas + changes on VRF systems + envelope improvement; Model T3: expanding the demand for laptop; Ideal Model Ti

${ }^{\# 2}$ Building LI:Model R - reference; Model TI: extension of the conditioned areas; ModelT2: expansion of the conditioned areas + envelope improvement; ModelT3: extension of the conditioned areas IVRF + envelop improvement + window sun protection; Model T4:T3 + expansion of laptop demand; Ideal Model Ti

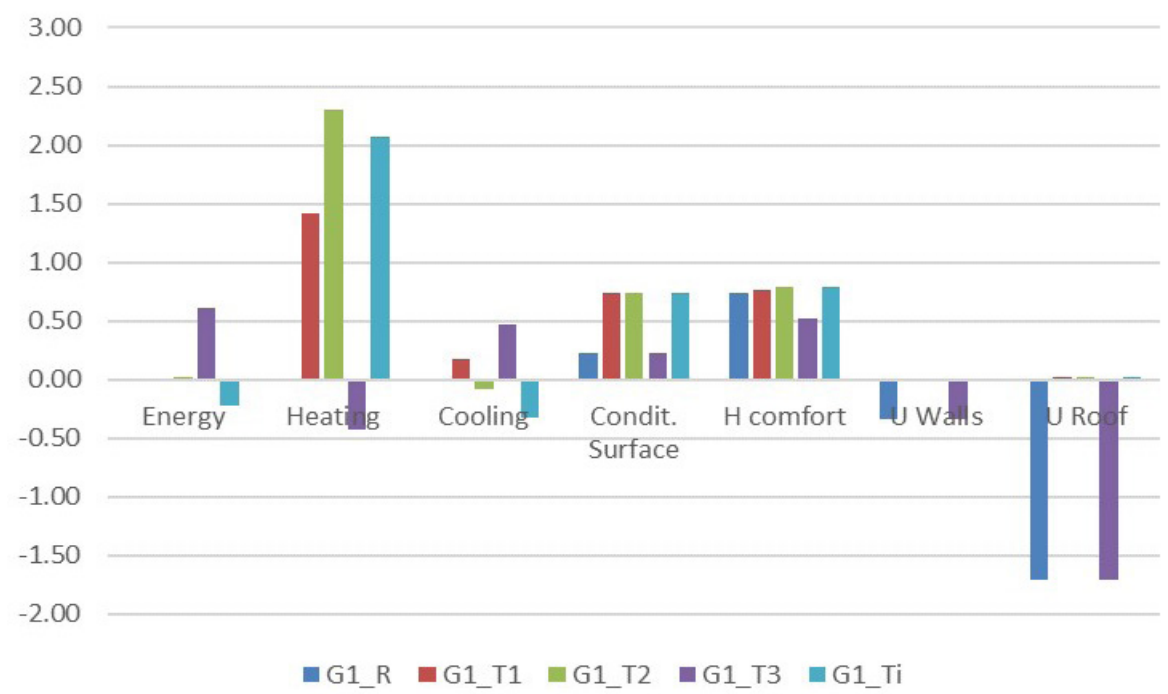

Figure I I Correlation between variables for GI building models.

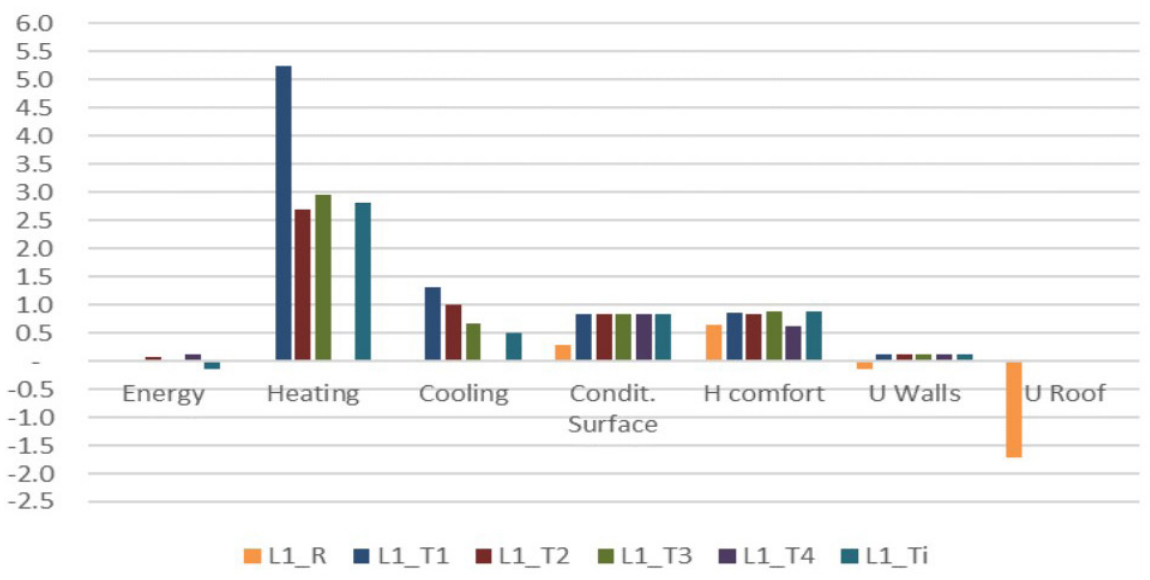

Figure 12 Correlation between variables for LI building models.

Figure 11 represents the G1 building and the Tideal (Ti) model assumes that, in order to achieve a higher level of thermal comfort in occupied hours (Comfort Hours $=0.789$ ), there is a corresponding increase in energy consumption for heating (2.065); in addition to the expansion of the conditioned area (0.743). For different purposes, the energy would be below the reference model, G1_R: -0.220 for general uses and 0.328 for cooling. For the envelop, the most relevant improvement is for U Roof, initially classified with low performance $(-1.712)$ to 0.024 in the Tideal.

On the other hand, for building L1 (Figure 12), model Tideal indicates that, in order to reach an increase in Thermal Comfort Hours 
(0.883), and respective expansion of the Conditioned Area (0.846), contributions for Cooling are needed $(0.505)$ at a level high above Heating (2.810). The U Roof impact improvement index is of 0.003 when compared to the value of -1.717 on the existing building model R.

In regard to the differences among the distinct simulation models, graphs point out that heating is the most relevant aspect, in meeting the demands of thermal comfort during cold periods. This is particulary important in this climatic context and also for roof quality improvement. In summary, Tfinal models results on energy impacts indicate the following:

- G1 - Expanding the conditioned area, changing air conditioning systems (VRF) and improving envelope estimates a $3.30 \%$ increase in energy consumption;

- L1 - In addition to the conditioned area expansion and envelope improvement; sun protection on large existing window surfaces, indicated a $13.92 \%$ increase in energy consumption.

Based on these data, it is possible to state that supporting thermal comfort conditions means improving the envelope and conditioning permanent used spaces. It means proposing integrated investments that go beyond the installation of air conditioning systems (commonly proposed by UPF's administration). Each specific action must be contextualized and include long-term economic results. However, the projections obtained from theoretical models only serve as guidance, to be assessed within the goals of University's PDI Institutional Development Plan. As proposed by UPF's strategic plan, it is important to note that isolated investments in air-conditioning can certainly expand the use of energy resources and consequently, positively impact the institution financially. They do not necessarily mean an improvement on environmental efficiency and conditions of use.

\section{Lines of action}

Towards the end of Phase 3, lines of action were established to improve energy demands, conditioning equipment performance and management and overall factors that affect the energy consumption in this study. These guidelines were indicated as measuring packages and priorities, which integrate three factors. Table 5 summarizes these lines of action.

Table 5 Lines of Action

Adjustments in use and occupancy profiles, with attendance of at least $80 \%$ thermal comfort in occupied hours (percentage of thermal comfort hours); Improvement of facade performance, adapting to indicated minimum values of $U \leq 1.00 \mathrm{~W} / \mathrm{m}^{2} \mathrm{~K}$ - level "A" by the RTQ-C; $43,44,58$

Quality improvement through roof rehabilitation, with $\mathrm{U} \leq 0.50 \mathrm{~W} / \mathrm{m}^{2} \mathrm{~K}$ for conditioned buildings and U $\leq \mathrm{I} .00 \mathrm{~W} / \mathrm{m}^{2} \mathrm{~K}$ for non-conditioned ones - "A" RTQ-C level;

Introduction of sunscreens on building LI

Adoption of strategies to guarantee natural ventilation, summer parameters of $0.19 \mathrm{~m} / \mathrm{s}$ and winter parameters of $0.16 \mathrm{~m} / \mathrm{s}$, with air renewals $>27 \mathrm{~m} / \mathrm{hour} \times$ person;

Management of individual actions to obtain thermal comfort conditions according to adaptive criteria;

Continuous maintenance of existing conditioning systems;

Adoption of setpoint heating temperatures of $20^{\circ} \mathrm{C}\left(68^{\circ} \mathrm{F}\right)$ and $26^{\circ} \mathrm{C}\left(78.8^{\circ} \mathrm{F}\right)$ for cooling, increasing the normative limits of current RTQ-C of $22^{\circ} \mathrm{C}\left(7 \mathrm{I} .6^{\circ} \mathrm{F}\right)$ and $24^{\circ} \mathrm{C}\left(75.2^{\circ} \mathrm{F}\right)$, respectively;

Gradual conditioning system replacement according to energy performance criteria, preferably at reverse-cycle A-rated VRF (RTQ-C) systems: CoP 3.8I for installations lower than $19 \mathrm{~kW}$ and $3.22 \mathrm{CoP} / 3.78 \mathrm{CoP}$ for installations between $19 \mathrm{~kW}$ and $40 \mathrm{~kW}$;

Lighting systems retrofitting, with savings of approximately $47 \%$;

Adjustments of computer equipment and laboratory performance, as well as their conditions and usage profile, targeting the consumption of targeted buildings Identification and reduction of "bottom consumption" that implies a certain amount of energy losses, identified in the periods of least occupation and use.

Even when the current study presents detailed results from each of the real and theoretical models; it is imperative to point out to a major issue: the increased electric energy consumption costs. Hence, it becomes relevant to invest in new systems and envelope changes, which target procedures that convert non-measurable variables into financial measures such as thermal comfort conditions of academic environments (classrooms, offices, laboratories, etc.) and its use. Some of these guidelines have already been incorporated into UPF's strategic plans, but they have not been concretely and efficiently implemented.

\section{The decision-making process}

According to Tomashow, ${ }^{13}$ energy is fundamental to the organization of campus sustainability efforts. In order to obtain positive results, it is essential that decision-making processes be inclusive and participatory. For that reason, as pointed by Frandoloso et al. ${ }^{6}$, it is important to incorporate essential mechanisms that include energy efficiency or more broadly eco-efficiency methodologies into the organizational structure of the University of Passo Fundo.
For this purpose, to further development the current structure and operational improvements were identified. It was initially based on UPF's strategic planning and currently awaits faculty and staff revisions. Additionally, an applicability control system and systematic evaluation process could be proposed as well.

An important detail for this procedure's positive outcome is related to administrative decisions regarding forming a specific sector for energy management. Former management proposals have not been implemented, meaning that the SmartGateM system is not currently operating.

As mentioned previously, conditioning classrooms and other university sectors are part of UPF's Institutional Development Plan - PDI 2012-2016, ${ }^{59}$ which was proposed to be executed by the end of 2016. In the institution's current Development Plan, PDI 2017-2021, ${ }^{60}$ such proposition was generalized in order to "qualify environmental, working and studying conditions". Such action gave visibility to these issues by promoting better diagnosis and evaluating alternative options. 
Two additional actions from PDI's plan entail describing work and study environment conditions: "Permanent campaigns are implemented in order to raise awareness and rationalize resource usage", "An institutional program is also developed to manage a sustainable environment and promote eco-efficiency". Although it was a program elaborated under the provost's responsibility, which was planned to be executed by December 2013; both actions are yet to be completed. In the institution's current Development Plan, these actions were permanently and retroactively modified in order to "update sustainable, environmental, ecoefficiency and the social responsibility of institutional programs".
Although environmental policies (PAI) have been developed ${ }^{61}$ by two thematic axes: a. energy efficiency, b. planning, construction and space occupancy; principles and goals were outlined based on their guidelines. However, their respective responsibilities and deadlines were not taken into account. In other words, the effective decisionmaking process is still open; but the necessary methodologies or indicators to actually achieve pre-established challenges were not determined; Table 6 below presents key principles and goals for energy efficiency.

Table 6 Principles and goals for energy efficiency ${ }^{61}$

\begin{tabular}{lll}
\hline Theme & Principles & Goals \\
\hline Energy Efficiency & Energy efficiency in all sectors; & Optimization of energy use; \\
& $\begin{array}{l}\text { Management and minimization of energy waste; Research } \\
\text { about new non-conventional and sustainable energy sources. }\end{array}$ & $\begin{array}{l}\text { Implementation of an integrated program and measures to } \\
\text { control energy waste; }\end{array}$ \\
& & $\begin{array}{l}\text { Reduction of energy related consumption costs; Promotion } \\
\text { of research projects that focus on sustainable energy } \\
\text { generation. }\end{array}$ \\
\hline
\end{tabular}

The water consumption is proposed in an integrated perspective to modernize and adapt the infrastructure of the campuses to follow the good practices of environmental sustainability, for example, the rainwater use and the protection of water resources from exclusively its own sources located on campus I. Solid waste, liquid effluents, and emissions generated in the activities and UPF sectors should be adequately managed, with the rational use of natural and material resources, to reduce and prevent pollution and to preserve or improve the quality of the environment, following the current rules and legislation.

As a result of the research methodology steps, in Phase 4, the lines of action were included to contribute into the decision-making process. It is considered part of UPF's planning-Institutional Development Plan, as well as an intervention proposal into the «Program of environmental and eco-efficiency energy «designed for University of Passo Fundo, according to Table 7.

Table 7 UPF's Environmental and Energy Efficiency Program

Analysis of the buildings' useful life span and the application of sustainable construction principles;

Construction parameter revisions for new buildings, using the appropriate envelope based on the minimum requirements of $U$ indicated by the RTQ-C, as well as by thermal bridge treatment;

Adoption of solar orientation definition criteria, suitable for habitability restrictions of different architectural programming sectors, such as artificial conditioning laboratories located between SW and SE directions, with lower radiation gains; classrooms, offices and teachers' rooms preferably located between NNW and E solar orientations;

Lamp replacement by LED systems whenever possible, or by high-performance fluorescents;

Lighting and dimerization sensors installation in extended-stay rooms lighting systems;

Retrofit programs, with the implementation of improved thermal comfort conditions, in at least $80 \%$ of used hours, which corresponds to the complex local climatic conditions (hot/humid in summer and cold/humid in winter);

Artificial conditioning with maximum setpoint temperatures of $20^{\circ} \mathrm{C}\left(68^{\circ} \mathrm{F}\right)$ in winter and minimum of $24^{\circ} \mathrm{C}\left(75.2^{\circ} \mathrm{F}\right)$ in summer;

Replacement of split direct expansion air conditioning systems by VRF systems with COPs greater than 4.0;

Application of either mechanical ventilation systems (if necessary, according to usage) or natural cross ventilation, as indicated by the Psychrometric Chart guidelines as well as the evaluation of adaptive comfort results;

Inclusion of window frames with external sun protection to ensure reduction of solar gains, associated with passive heating strategies;

Development of a user awareness program regarding the use and operation of air conditioning systems (setpoints); use and operation of windows and internal protection systems; as well as the activation of lighting systems.

Reestablishment of control programs and monitoring of the resources developed by the Campus Conservation Sector, such as SmartGateM - Gestal, a system applied to electric energy consumption, and adoption of smart grids systems.Application of demand side response - an automated electric grid demand control that reduces energy peaks and costs due to differences in consumption rates. Additionally, it is also financially beneficial, as it associates the generation and distribution provider with the consumer - UPF;

Identification of generation source of consumption funds and proposition of consumption limits in peak hours for consumer units or academic units;

Low efficiency motor replacement by $80 \%$ or more;

Elevators retrofit by systems with regenerative braking and low power in standby;

Promotion and implementation of efficient use of natural resources (water, materials, mobility and $\mathrm{CO}_{2}$ emissions, solid waste, etc.) and reduction of associated environmental impacts, following UPF's Socio-Environmental Responsibility Policy (Dalmolin and Moretto 2016). 
Finally, the establishment of these guidelines for the institution's rating and, consequently, a greater energy efficiency for UPF's building stock, on both new and existing buildings, must be included in a whole Institutional Environmental Policy (in Portuguese: PAI). PAI is supposed to be resumed under administrative direction, serving as an effective tool to deal with sustainable issues at University of Passo Fundo.

The evolution of the actions and practices on the operation of the sustainability by UPF shows an increasing of the measures to achieve energy effectiveness. Among the actions are the use of electricity from exclusively renewable sources since 2018 , with a reduction in emissions of around 96.8 tons $\mathrm{CO}_{2}$. A solar photovoltaic park was built recently with a surface of $108 \mathrm{~m}^{2}$ and the capacity to produce $17.82 \mathrm{kWp}$; energy production in the initial twelve months totalled $22,245 \mathrm{kWp}$, an output of saving money and approximately 22.3 tonCO $\mathrm{C}_{2}$ that were not emitted to the atmosphere.

Some procedures of lighting retrofit also were implemented in the lats years, for instance was achieved a reduction of $60 \%$ in energy consumption in the public lighting, besides changes with the substitution of ordinary and inefficient lamps to LED systems. All these policies and actions shows that administrative changes are happening in the UPF structure, recognized by the sustainable ranking of UI Green Metrics, ${ }^{62}$ that the university take part since 2020.

\section{Discussion}

To improve UPF's environmental and social commitment, the university premises can promote favourable living conditions, citizenship recognition, social coexistence among racial, ethnic and gender diversity, which are essential for solidarity and urbanity. Thus, the Social Responsibility Policy - RSU participative process ${ }^{63}$ was developed in 2014. Such policy included five axes such as: a) organizational governance; b) human rights promotional practices; c) community involvement and development; d) cultural, environmental responsibility and preservation practices; e) dignifying working practices and; f) fair marketing towards subjects who seek higher level education. According to Leal Filho et al. ${ }^{5}$ all these approaches increase sustainable leadership and initiatives when applied as an open and continuous process. It means that the needs of subjects included in this research reflect the guidelines of both university policies, the RSU and the current PDI. It shows it is a feasible tool to assess and qualify energy performance of UPF's building stock. ${ }^{26}$

As mentioned previously, the monitoring and analysis of energy patterns is proposed by Alshuwaikhat and Abubakar, ${ }^{19}$ Faghihi et al. ${ }^{23}$ and Amber et al. ${ }^{24}$. The lack of a sustainable approach in most universities worldwide indicated by the authors, is not completely accurate for UPF, because over the past few years, normative and practical experiences have been addressing these issues at UPF. In addition, the present research also promotes sustainable changes related to environmental aspects. The EMS proposed by Alshuwaikhat and Abubakar ${ }^{19}$ is current developed by UPF's Environmental Management System Guidelines. ${ }^{64}$ The RSU reached to another approach which in turn encompasses public participation and social responsibility.

The methodology applied at UPF Figure $1 \& 2$ and the guidelines proposed by this study (Table $4 \& 6$ ) agrees with Alshuwaikhat and Abubakar's ${ }^{19}$ assumption. It establishes priorities and contributes to the decision-making process, indicated by the modelling found at Faghihi et al. ${ }^{23}$ and Amber et al. ${ }^{24}$. Both methodologies can contribute to future development at UPF's building stock and specially to other similar typologies in carrying out audits in the future.
UPF's Environmental and Energy Efficiency Program, also accords with Treu. ${ }^{14}$ It claims that an institution's research and energy source management, its economical and sustainability objectives (resources optimization) as well as its environmental compatibility (increasing use of renewable resources, for instance) require budgeting that controls the accessibility of different energy sources.

\section{Conclusion}

UPC's methodology, used as a reference for UPF proved to be feasible. However, it needed to be adapted to the local institutional needs. The core changes were related to the differences in energy usage, which were mainly associated to heating at UPC (the Spanish university setting) and to refrigeration and equipment at UPF (Brazilian university setting). As a result, this methodology enabled the verification of incident factor's impact on energy consumption in selected buildings.

The modelling by DesignBuilder for improved energy and thermal performance, indicates the possibility to present different scenarios to evaluate pre-existent conditions. It allows qualifying and adjusting all building factors and its use by using simulations. As a result, the degree of eco-efficiency for each theoretical model can be compared to corresponding reference or real models.

Similarly, the developed models assessed the conditions of indoor thermal comfort, including simulations for envelope thermal performance improvement (walls and roofs). It was pointed as deficient in comparisons to Brazilian regulatory parameters. However, it was later integrated to UPF's institutional policies regarding thermal conditioning and usage, as well as in a requirement indicated by tools to evaluate climatic context.

Considering the present results, it can be said that, in order to promote thermal comfort conditions combined with energy and thermal performance improvement; one must make integrated investments. Each of the concrete actions must be contextualized and integrated into long-term economic results. The theoretical model scenarios only present one reference point.

The action guidelines and intervention proposals were included within an «Environmental and Energy Efficiency Program for the university». They especially reflected on the institution's decisionmaking processes. This program aims to address the Institutional Environmental Policies about administrative and academic procedures. However, it is up to University of Passo Fundo to reinforce a structure that generates a paradigm change and concrete goals in all its built park.

In terms of UPF's planning and decision-making processes, the University's view regarding sustainability is still facing early stages of implementation, as it has been identifying institutional procedures to include environmental and social policies into academic regulations. It is imperative to reinforce the structure generated by this new vision so that it can turn into real goals and actions. It is important to always keep in mind, however, previously formulated goals which are to be effectively implemented and revised in a continuous feedback process.

The main aspect to be highlighted, however, is the result of the agglutination of isolated actions that are developed by administrative research groups responsible for UPF's management. These actions should converge into union's efforts, and especially integrate all community participants such as students, faculty members, technical, administrative and maintenance staff. New future researches may be generated from the present work, that seeks to evaluate different buildings and to achieve balance and compatibility between comfort 
and economic costs. In that way, it's important to proceed a proper economic analysis of each strategy to improve envelop quality and indoor conditions.

The construction of social and environmental policies certainly indicates a paradigm change at UPF. However, it is essential to establish effective procedures that incorporate sustainability throughout the university campus, and that constant generate commitment and responsibility at every stage of its decision-making process. An open channel of communication between society and university is essential. It is especially vital for the university's philanthropic nature, as it consequently expands the institutions' role to promote education practices and regional sustainability.

It is important to contribute to a continuous discussion about universities leadership facing sustainable challenges, in order to improve and increase proactive methods and procedures within administrative and academic activities, which involve all stakeholders. In a wider perspective, these subjects can collaborate to reduce the current gaps for achieving the Sustainable Development Goals, not only the specific SDG 7, but in an integrated way with the whole closer 2030 Agenda.

\section{Acknowledgments}

The authors would like to thank to University of Passo Fundo (UPF) and Polytechnic University of Catalonia (UPC) for the support and colla.

\section{Conflicts of interest}

The authors declare have no conflicts of interest.

\section{References}

1. ULSF. University Leaders for a Sustainable Future. Declaración de Talloires: declaración de líderes de universidades para un futuro sostenible. 1990.

2. UNESCO. Draft International Implementation Scheme for the UN Decade of Education for Sustainable Development (2005-2014). 2004.

3. Leal Filho W. The United Nations Decade of Education for Sustainable Development: lessons learnt and needs to be met. Intern. Journal of Sustainability in Higher Education. 2014;15:2.

4. UNESCO. Shaping the future we want. UN Decade of Education for Sustainable Development (2004-2014). Final Report. 2014.

5. Leal Filho W, Eustachio JHPP, Caldana ACF, et al. Sustainability Leadership in Higher Education Institutions: An Overview of Challenges. Sustainability. 2020;12:3761.

6. Frandoloso MAL, Cuchí i Burgos A, Cunha EG Da. The application of eco-efficiency in university buildings: policies and decision-making process, In: Leal Filho W, et al., editors. Towards Green Campus Operations: Energy, climate and Sustainable Development Initiatives at Universities. Springer, Berlin, 2018. p. 141-158.

7. Tavares SF. Methodology for analyzing the energy life cycle of Brazilian residential buildings "Metodologia de análise do ciclo de vida energético de edificações residenciais brasileiras”. Programa de Pós-Graduação em Engenharia Civil. Universidade Federal de Santa Catarina. 2006.

8. Medeiros LM, Durante LC, Callejas IJA. Contribution to life cycle assessment in the quantification of environmental impacts of construction systems "Contribuição para a avaliação de ciclo de vida na quantificação de impactos ambientais de sistemas construtivos". Ambiente Construído. 2018;18(2):365-385.
9. John VM, Oliveira DP, Lima JAR. State of the Art survey: material selection. FINEP 2386/04 Project: Technologies For more sustainable housing construction "Levantamento do estado da arte: seleção de materiais. Projeto FINEP 2386/04: tecnologias para a construção habitacional mais sustentável". 2007.

10. EPE. Empresa de Pesquisa Energética. Atlas da Eficiência Energética Brasil 2019. Relatório de Indicadores. 2020.

11. Souza UEL, Deana DF. State of the Art Survey: consumption of materials FINEP 2386/04 Project: Technologies For more sustainable housing construction "Levantamento do estado da arte: consumo de materiais". Projeto FINEP 2386/04: tecnologias para a construção habitacional mais sustentável. 2007

12. Araújo VM, Cardoso FF. Analysis of environmental aspects and impacts of construction sites and their correlations "Análise dos aspectos e impactos ambientais dos canteiros de obras e suas correlações". Boletim Técnico da Escola Politécnica da USP, BT/PCC/544. 2010.

13. Tomashow M. The nine elements of a sustainable campus. MIT Press, Cambridge, USA, 2014

14. Treu MC. Energy. Territory and New Landscapes Scenarios. City, Territory and Architecture An interdisciplinary debate on project perspectives. 2018;5:14.

15. Wilson EO. Biophilia. Harvard University Press, Cambridge, MA, 1984.

16. Kellert SF, Heerwagen JH, Mador ML. Biophilic Design. Wiley, Hoboken, NJ, 2018

17. Abdelaal MS. Biophilic campus: An emerging planning approach for a sustainable innovation-conducive university. J Clean Prod. 2019;215:1445-1456.

18. United Nations. Sustainable Development Outlook 2020: Achieving SDGs in the wake of COVID-19: Scenarios for policymakers. 2020.

19. Alshuwaikhat HM, Abubakar I. An integrated approach to achieving campus sustainability: assessment of the current campus environmental management practices. J Clean Prod. 2008;16:1777-1785.

20. ISO. International Organization for Standardization. ISO 14001: 2015 Environmental management systems - Requirements with guidance for use. ISO, Genève, 2015

21. Velazquez L, Munguia N, Platt A, et al. Sustainable university: what can be the matter? J Clean Prod. 2006;14:810-819.

22. Viebahn P. An environmental management model for universities: from environmental guidelines to staff involvement. J Clean Prod. 2006;10:312

23. Faghihi V, Hessami AR, Ford DN. Sustainable campus improvement program design using energy efficiency and conservation. $J$ Clean Prod 2015; 107:400-409.

24. Amber KP, Aslam, MW, Mahmood A, et al. Energy consumption forecasting for university sector buildings. Energies. 2017;10:1579.

25. Drahein AD, Lima EP de, Costa SEG da. Sustainability assessment of the service operations at seven higher education institutions in Brazil. J Clean Prod. 2019;212:527-536.

26. Frandoloso MAL. The insertion of energy efficiency in Brazilian University buildings: policies and decision-making processes "La inserción de la eficiencia energética en los edificios universitarios brasileños: las políticas y los procesos de toma de decisiones". Tesis (Doctorado). Departament de Tecnologia em l'Arquitectura. Programa de Doctorat en Arquitectura, Energía i Medi Ambient. Escola Tècnica Superior d'Arquitectura. Universitat Politècnica de Catalunya. UPC, Barcelona, 2018. 
27. Ferrer-Balas D, Buckland H, de Mingo M. Explorations on the University's role in society for sustainable development through a system transition approach. Case study of the Technical University of Catalonia (UPC) $J$ Clean Prod. 2009;17(12):1075-1085.

28. Cuchí i Burgos, A. The environmental quality in buildings "La qualitat ambiental als edificis". Generalitat de Catalunya, Barcelona, 2009.

29. Braungart M, McDonough W. Cradle to cradle. remaking the way we make things. Vintage Books, London, 2009.

30. Braungart M, McDonough W. The Cradle to Cradle Framework. 2012.

31. UPC. Universitat Politècnica de Catalunya. UPC 2020 Energy sustainable communities "UPC Energia 2020 - Comunitats sostenibles". UPC, Barcelona, 2017.

32. Pérez-Foguet A, Lazzarini B, Giné R, et al. Promoting sustainable human development in engineering: Assessment of online courses within continuing professional development strategies. J Clean Prod. 2018;172:4286-4302.

33. Frandoloso MAL. Sustainability on campus (examples), In: Azeiteiro U, et al., editors. Encyclopedia of Sustainability in Higher Education. Springer, Berlin, 2019. Ch. 28.

34. Bosch Gonzales M, López F, Rodríguez I. Energy evaluation of buildings. $U P C$ experience "Avaluació energètica d'edificis: experiència de la UPC”. UPC, Barcelona, 2006

35. Catalapiedra IR, Bosch M, López F. Involvement of final architecture diploma projects in the analysis of the UPC buildings energy performance as a way of teaching practical sustainability. J Clean Prod. 2006;14:958962.

36. López Plazas F. On the use and management as the main factors that determine the energy consumption in the building "Sobre el uso y la gestión como los factores principales que determinan el consumo de energía en la edificación". Tesis (Doctorado), Escola Tècnica Superior d'Arquitectura, Universitat Politècnica de Catalunya. UPC, Barcelona, 2006.

37. UPC. Universitat Politècnica de Catalunya, Oficina per a la Gestió Sostenible. How does a POE? "Com funciona un POE?" Barcelona: Recursos i Serveis per a la Gestió Sostenible - UPC, 2012

38. GESTAL. Smart Gate M. Retrieved on 29 Jan. 2009

39. Design Builder. DesignBuilder EnergyPlus Simulation Documentation DesignBuilder v4.2.0.054. 2014.

40. Lange AL, Reginatto G, Brandli LL, et al. Analysis of energy consumption and efficiency at University of Passo Fundo - Brazil, In: Leal Filho W, et al., editors. Towards Green Campus Operations: Energy, climate and Sustainable Development Initiatives at Universities. Springer, Berlin, 2018. p. 519-533.

41. ABNT. Associação Brasileira de Normas Técnicas. NBR 15220 Thermal performance of buildings "NBR 15220: desempenho térmico de edificações”. ABNT, Rio de Janeiro, 2005.

42. ABNT. Associação Brasileira de Normas Técnicas. NBR 15575: housing buildings - performance "NBR 15575: edifícios habitacionais desempenho". ABNT, Rio de Janeiro, 2013.

43. PROCEL. Technical regulation on the quality of the energy efficiency level of commercial, service and public buildings (RTQ-C) "Regulamento técnico da qualidade do nivel de eficiencia energética de edificios comerciais, de serviços e públicos (RTQ-C)”. PROCEL/Eletrobras, vol. 2. $2010 \mathrm{a}$

44. PROCEL. Manual for application of RTQ-C "Manual para aplicação do $R T Q-C$ ”. Rio de Janeiro: PROCEL/Eletrobras, 2013.

45. Fanger PO. Thermal comfort: analysis and application in environmental engineering. Danish Technical Press, Copenhagen, 1970.
46. Fanger PO, Toftum J. Extension of the PMV model to non-air-conditions buildings in warm climates. Energy and Buildings. 2002;34:533-536.

47. ISO. International Organization for Standardization. ISO 7730 Ergonomics of the thermal environment - Analytical determination and interpretation of thermal comfort using calculation of the PMV and PPD indices and local thermal comfort criteria. ISO, Genève, 2005.

48. ASHRAE. American Society of Heating, Refrigerating and Airconditioning Engineers. ASHRAE Standard 55: Thermal environmental conditions for human occupancy. ASHRAE, Atlanta - USA, 2004.

49. Humphreys M, Nicol JF. Understanding the adaptive approach to therma comfort. ASHRAE Technical Data Bulletin. ASHRAE, Atlanta - USA. 1998;14(1):1-14.

50. Humphreys MA, Nicol JF. The validity of ISO-PMV for predicting comfort votes in every-day thermal environments. Energy and Buildings. 2002;34(6):667-684.

51. de Dear RJ, Brager GS. Developing an adaptive model of thermal comfort and preference. ASHRAE Technical Data Bulletin. ASHRAE, Atlanta USA, 1998;14 (1):27-49.

52. de Dear RJ, Brager GS. Thermal comfort in naturally ventilated buildings: revisions to ASHRAE Standard 55. Energy and Buildings. 2002;34(6):549-561.

53. ASHRAE. American Society of Heating, Refrigerating and Airconditioning Engineers. 2009 ASHRAE Handbook Fundamentals. ASHRAE, Atlanta - USA, 2009

54. Negreiros B de A. Analysis of methods of prediction of thermal comfort of housing in hot-humid climate with passive conditioning "Análise de métodos de predição de conforto térmico de habitação em clima quente-úmido com condicionamento passivo”. Dissertação (Mestrado) Universidade Federal do Rio Grande do Norte, Departamento de Arquitetura e Urbanismo, Programa de Pós-Graduação em Arquitetura e Urbanismo. UFRN, Natal - RN, 2010.

55. Samouilidis J. Energy modelling: a new challenge for managemen science. Omega. 1980;8(6):609-621.

56. Chwif L, Medina AC. Modelagem e Simulação de Eventos Discretos: Teoria e Aplicações. São Paulo, 2007.

57. Rebelatto BG, Frandoloso MAL. Energy modelling: methods and applications. In: W Leal Filho, et al., editors. Affordable and Clean Energy, Encyclopedia of the UN Sustainable Development Goals. v.1. Cham, Switzerland: Springer, 2020, p. 459-470.

58. UPF. Universidade de Passo Fundo. Institutional development plan: fiveyear plan for the institutional development of UPF 2012-2016 "Plano de desenvolvimento institucional: plano quinquenal para o desenvolvimento institucional da UPF 2012 - 2016". GPI - UPF, Passo Fundo, 2012.

59. UPF. Universidade de Passo Fundo. Institutional development plan five-year plan for the institutional development of UPF 2017-2021 "Plano de desenvolvimento institucional: plano quinquenal para o desenvolvimento institucional da UPF 2017 - 2021. Comissão do Plano de Desenvolvimento Institucional, Passo Fundo, 2016.

60. PROCEL. Regulation on the conformity assessment of the level of energy efficiency of commercial, service and public buildings (RAC-C) "Regulamento de avaliação da conformidade do nível de eficiência energética de edifícios comerciais, de serviços e públicos (RAC-C)". PROCEL/Eletrobras, vol. 3, 2010b.

61. Mistura C, Passini ACF, Foschiera EM. Social development Policy - UPF environment "Política de desenvolvimento social - meio ambiente da $U P F$ ”. UPF: Comissão de Elaboração da Política de Responsabilidade Social e Meio Ambiente, Passo Fundo, 2013.

62. UI Green Metric. Overall rankings 2020. UI, 2020. 
63. Dalmolin BM, Moretto CM, organizers. Social Responsibility Policy 2013/2016 "Política de responsabilidade social 2013/2016". Ed. Universidade de Passo Fundo, Passo Fundo, 2014.
64. Assumpção LFJ, Peluso RMB, Freschi M. Manual of Environmental Management System, "Manual do sistema de gestão ambiental", UPF, Passo Fundo, 2011. 